\title{
KADAR AIR DAN TOTAL BAKTERI DAGING KAMBING YANG DIBERI ASAP CAIR TONGKOL JAGUNG DAN TEMPURUNG KELAPA
}

\author{
Mokmin $^{1}$, Wahyu Mushollaeni ${ }^{2}$, Budi Santosa ${ }^{3}$ \\ ${ }^{1}$ Alumni Universitas Tribhuwana Tunggadewi Jl. Tlaga Warna Blok C Tlogomas Malang \\ ${ }^{2,3}$ Dosen Program Studi TIP Unversitas Tribhuwana Tunggadewi
}

\begin{abstract}
corn cobs and coconut shell are a type of waste that can be used as a raw material of to produce liquid smoke. The reseach used randomized block design two factors which fist factor is a type of liquid smoke (corn cobs, coconuts shell) and the second factor is liquid smoke concentration $(1 \%, 1.5 \%, 2.0 \%, 2.5 \%)$. The parameters experiment include are water content and total bacteria (TPC) of the lamb. The result showed of treatment has not significant effect of water content of lamb and the concentration liquid smoke of the corn cobs and liquid smoke of the coconut shell significant effect to total bacteria of lamb. The lowest total bacteria on treatment liquid smoke of corn cobs with concentration $2.5 \%$ that is showed $1.5 \times 10^{7} \mathrm{cfu} / \mathrm{g}$ lamb.
\end{abstract}

Keywords: meat, liquid smoke concentration, TPC, water content

\section{PENDAHULUAN}

Pengolahan tongkol jagung dan tempurung kelapa menjadi asap cair merupakan salah-satu upaya penting dalam meningkatkan nilai ekonomi kedua hasil samping produk pertanian tersebut. Terdapat 400 komponen fungsi pada asap cair yang dapat berfungsi sebagai penghambat perkembangan bakteri dan cukup aman sebagai pengawet alami. Asap cair mengamdung zat pengawet alami yang berupa asam fenolat dan karboksil

Asap cair dikelompokkan beberapa grade tergantung proses pemurniannya. Asap cair grade 3 adalah asap cair yang masih mengandung tar dan benzonpiren yang tinggi sehingga tidak aman untuk diaplikasikan pada produk pangan. Asap cair yang aman untuk poduk pangan adalah grade 1 yang mana berasal dari asap cair grade 3 yang telah diproses lebih lanjut. Saat ini asap cair dibuat dari beberapa bahan baku diantaranya kayu, bonggol kelapa sawit, serbuk kayu hasil samping penggergajian (Kamulyan, 2008).

Daging kambing merupakan salah satu hasil peternakan yangsangat mudah mengalami kerusakan karena mengandung air yang cukup tinggi yaitu berkisar $68-75 \%$. Daging kambing juga mengandung sejumlah karbohidrat yang dapat difermintasi oleh mikrooganisme sehingga menimbulkan kerusakan.

Soeparno (2005) menyebutkan bahwa daging mengandung berbagai komponen yang menguntungkan bagi pertumbuhan 
mikrooganisme diantaranya karbohidrat dan mineral serta didukung oleh $\mathrm{pH}$ yang dapat memicu tumbuhnya mikroorganisme.

Pada umumnya proses pengasapan daging dengan asap cair dilakukan dengan cara mencelupkan daging pada larutan asap cair dan air bersih. Dengan demikian senyawa asap akan menempel pada daging yang diasap. Asap cair tersebut akan membentuk aoma dan rasa yang khas pada daging dan memberikan warna tertentu seperti keemasan atau kecoklatan (Adawiyah, 2008).

Tempurung kelapa adalah salah satu hasil samping dalam pengolahan kelapa menjadi minyak maupun kopra. Tempurung kelapa yang dipirolisis akan menghasilkan arang, tar, asap cair dan gas-gas. Asap cair saat ini telah diproduksi dan dimanfaatkan oleh perusahan sebagai bahan pengawet alami. Asap cair yang tersedia dipasaran memiliki tingkat keamanan yang berbeda tergantung gradenya. Asap cair yang dimanfaatkan untuk pengawetan bahan pangan adalah asap cair dengan grade terbaik karena selain dimaksudkan sebagai pengawet pada bahan pangan juga sebagai penambah aroma dan cita rasa khas daging asap.

Penelitian dilakukan untuk mengetahui kadar air daging kambing dan total bakteri (TPC) yang diberi asap cair berbeda yaitu tongkol jagung dan tempurung kelapa. Tongkol merupakan salah satu hasil samping produk jagung yang memiliki potensi baik untuk dijadikan asap cair kaena mengandung senyawa penting seperti fenol, asam, ester, aldehid dan hidrokarbon.
Kadar air dalam daging merupakan salah satu fakto pemicu terjadinya kerusakan untuk itu agar kerusakan dapat ditekan maka perlu diberkan perlakuan tertentu misalnya dengan menguragi atau menekan kadar air dalam bahan pangan. Kandungan bakteri pada bahan pangan merupakan salah satu indikator keemanan pangan tersebut untuk dikonsumsi. Menurut SNI yang diperbolehkan adanya angka lempeng total koloni bakteri pada daging asap adalah $1 \times 10^{10} \mathrm{koloni} / \mathrm{g}$.

\section{METODE PENELITIAN}

Penelitian dilakukan di Laboratorium Rekayasa Proses Fakultas Pertanian Universitas Tribhuwana Tunggadewi dan Laboratorium Ilmu dan Teknologi Pangan Universitas Muhammadiyah Malang.

Alat Bahan yang digunakan diantaranya asap cair tongkol jagung dan asap cair tempurung kelapa yang diperoleh dari Laboratorium Bioenergi Universitas Tribhuwana Tunggadewi Malang. Daging kambing diperoleh dari RPH balai besar rumah potong hewan Kabupaten Malang.

Bahan yang digunakan selenium mix, $\mathrm{H}_{2} \mathrm{SO}_{4}$ pekat, $\mathrm{NaOH} 30 \%$, asam boraks $3 \%$, aquades, media PCA, HCL $3 \mathrm{~N}, \mathrm{KBr}$, aluminium foil dan kapas.

Penelitian menggunakan Rancangan Acak Lengkap faktorial. Faktor satu adalah bahan baku yang digunakan pada pembuatan asap cair sedangkan faktor kedua adalah konsentrasi asap cair. Wibowo (2002) mengemukakan bahwa faktor penting yang harus diperhatikan dalam proses pengasapan cair dianratanya adalah konsentrasi asap cair 
yang digunakan, suhu serta lamanya waktu perendaman bahan yang diasap dalam larutan asap cair. Dalam Jenis bahan asap cair adalah:

$\mathrm{A} 1=$ tempurung kelapa

$\mathrm{A} 2=$ tongkol jagung

kombinasi perlakuan konsentrasi asap cair yang digunakan terdiri dari empat diantaranya adalah:

$11=1 \%$

$12=1.5 \%$

$13=2 \%$

$14=2.5 \%$

dari kedua faktor dalam perlakuan maka diperoleh kombinasi sebagaimana berikut:

1. A1 11

2. A1 12

3. A1 13

4. A1 14

5. A2 11

6. A2 12

7. A2 13

8. A2 14

Penelitian dilakukan dengan dua tahap yaitu persiapan alat dan bahan kemudian dilanjutkan dengan pengasapan daging kambing. Pengasapan diawali dengan pembuatan larutan asap sesuai dengan kombinasi perlakuan. Masing-masing konsentrasi asap cair diberikan $500 \mathrm{ml}$ air bersih. Diagram alir penelitian disajikan pada Gambar 1.
Daging kambing yang akan diasap dengan asap cair terlebih dahulu dilakukan perebusan kemudian direndam dalam asap cair sesuai dengan konsentrasi yang telah ditetapkan dalam perlakuan penelitian. Daging kambing yang direndam dalam larutan asap cair masing-masing 2 potong (100g/potong). Selanjutnya ditiriskan hingga permukaannya kering dan dioven selama 12 jam dengan suhu $40-80^{\circ} \mathrm{C}$.

Data hasil penelitian dikumpulkan dan dianalisis menggunakan ANOVA (analysis of varians). Jika dari uji ANOVA ditemukan perbedaan nyata maka dilanjutkan dengan uji DMRT (duncan's multiple range test) pada $\alpha 5 \%$.

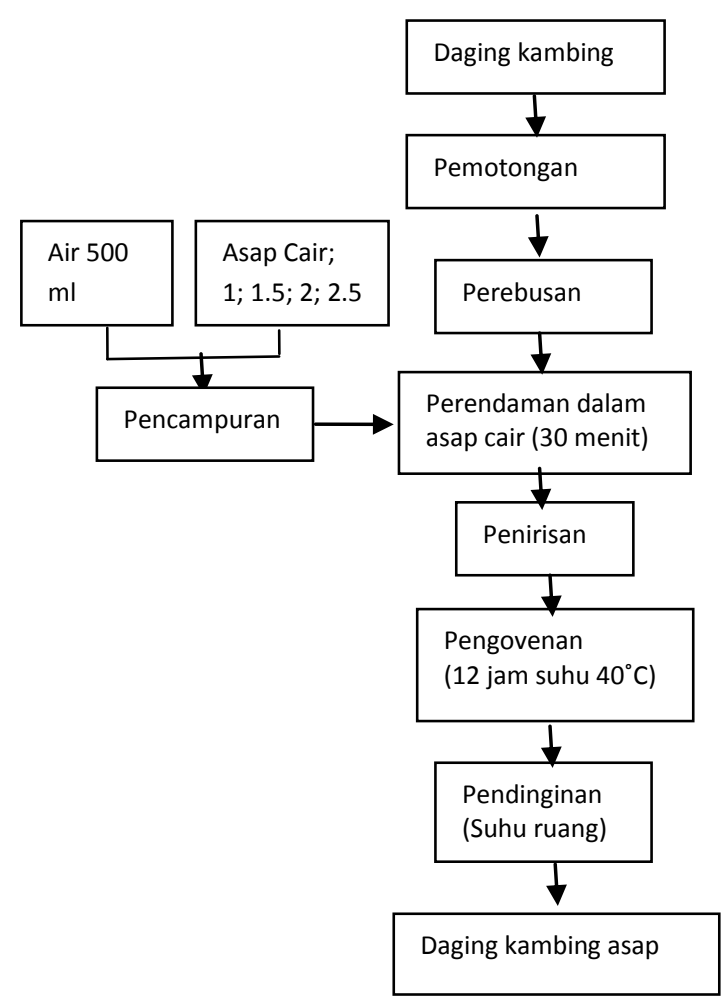

Gambar 1. Diagram Alir Penelitian 


\section{HASIL DAN PEMBAHASAN}

\section{Kadar Air}

Rerata kadar air daging kambing asap dengan menggunakan asap cair yang terbuat dari tempurung kelapa dan tongkol jagung pada konsentrasi berbeda menunjukkan bahwa tidak ada perbedaan nyata berdasarkan hasil analisis ANOVA karena nilai $f$ hitung lebih kecil dari $f$ tabel. Rerata kadar air tertinggi terdapat pada perlakuan A2 14 (asap cair tongkol jagung). Rerata kadar air daging kambing dari berbagai perlakuan disajikan pada Tabel 1 .

$\underline{\text { Tabel 1. Rerata Kadar Air Daging Kambing }}$

\begin{tabular}{lr}
\hline \multicolumn{1}{c}{ Perlakuan } & $\begin{array}{c}\text { Kadar Air } \\
(\%)\end{array}$ \\
\hline Tempurung kelapa 1\% & 23.68 \\
Tempurung kelapa 1.5\% & 25.36 \\
Tempurung kelapa 2 \% & 23.97 \\
Tempurung kelapa 2.5\% & 28.4 \\
Tongkol jagung 1\% & 15.1 \\
Tongkol jagung 1.5\% & 18.8 \\
Tongkol jagung 2\% & 22.72 \\
Tongkol jagung 2.5\% & 29 \\
\hline
\end{tabular}

Berdasarkan Tabel 1 dapat dilihat bahwa semakin tinggi konsentrasi asap cair yang digunakan, semakin tinggi kadar air dari daging kambing. Abustam dkk (2010) menyebutkan bahwa asap cair memiliki kemampuan dalam meningkatkan daya ikat air. Dengan demikian pada penelitian ini kadar air meningkat seiring dengan peningkatan konsentrasi penggunaan asap cair, baik dari asap cair yang terbuat dari tongkol jagung maupun daging kelapa.

\section{Total Bakteri}

Suryaningsih dkk

(2009) mengemukakan bahwa perendaman daging dengan konsentrasi $7.5-10 \%$ asap cair dari tempurung kelapa dapat berpengaruh terhadap total bakteri dan umur simpan daging. Pada penelitian ini berdasarkan uji ANOVA menunjukkan $\mathrm{f}$ hitung lebih tinggi dari pada $f$ tabel. Dengan demikian dapat dikatakan bahwa konsentrasi asap cair dari tongkol jagung dan tempurung kelapa berpengaruh terhadap total bakteri daging kambing.

Rerata total bakteri daging kambing tertinggi pada perlakuan asap cair tempurung kelapa dengan konsentrasi $2.5 \%$ ). Rerata total bakteri semua perlakuan disajikan pada Tabel 2.

Tabel 2. Rerata Total Bakteri Daging Kambing Asap

\begin{tabular}{lr}
\hline \multicolumn{1}{c}{ Perlakuan } & $\begin{array}{r}\text { Kadar Air } \\
(\%)\end{array}$ \\
\hline Tempurung kelapa 1\% & 4.15 \\
Tempurung kelapa 1.5\% & 7.8 \\
Tempurung kelapa 2\% & 7.55 \\
Tempurung kelapa 2.5\% & 8.4 \\
Tongkol jagung 1 \% & 4.15 \\
Tongkol jagung 1.5\% & 3.95 \\
Tongkol jagung 2\% & 3.15 \\
Tongkol jagung 2.5\% & 1.5 \\
\hline
\end{tabular}

Berdasarkan Tabel 2 dapat dilihat bahwa total bakteri terendah berada pada perlakuan asap cair tongkol jagung dengan dengan konsentrasi $2.5 \%$. Total bakteri pada perlakuan asap cair tongkol jagung dengan konsentrasi $2.5 \%$ adalah $1.5 \times 10^{7} \mathrm{cfu} / \mathrm{g}$.

Jika dilihat berdasarkan Standar Nasional Indonesia maka daging kambing 
asap yang dihasilkan dari perlakuan penelitian masih belum memenuhi standar. Total bakteri yang diperbolehkan SNI dalam daging asap adalah 01-3818-1995 adalah 1x $10^{5} \mathrm{kol} / \mathrm{g}$. Variasi perlakuan konsentrasi asap cair dalam penelitian ini dapat dikategorikan sangat rendah sebab pada penelitian-penelitian sebelumnya, untuk mengurangi total bakteri pada daging asap adalah dengan cara menggunakan asap cair $10 \%$.

Awal (2009) menyebutkan bahwa konsentrasi asap cair $10 \%$ dapat menghasilkan daging asap dengan total bakteri $25.40 \times 10^{6} \mathrm{cfu} / \mathrm{g}$ dan dapat memperpanjang umur siman hingga 1216 menit serta penerimaan panelis yang baik. Penerimaan tersebut didasarkan pada uji hedonik yang meliputi warna, aroma, rasa dan total penerimaan.

\section{KESIMPULAN DAN SARAN}

Bahan asap cair yang baik digunakan pada daging kambing berdasarkan hasil penelitianadalah asap cair dari tongkol jagung dengan konsentrasi 2,5\% menghasilkan asap cair dengan total bakteri $1,5 \times 10^{7} \mathrm{cfu}$ dan kadar air 1,5\% berat bahan.

Perlu dilakukan penelitian lanjutan yang berkaitan dengan jenis bakteri yang terkandung dalam asap cair serta perlu dilakukan penelitian penggunaan jenis bahan baku asap cair lainnya yang berasal dari hasil samping komoditi pertanian.

\section{DAFTAR PUSTAKA}

Abustam, E. d. (2010). Kemampuan Mengikat Air (Water Holding
Capacity) dan Daya Putus Daging Sapi Parigor Melalui Tingkat Penambahan Asap Cair.

Awal, A. A. (2012). Penggunaan Asap Cair pada Daging dan Pengaruhnya Terhadap Kualitas Daging. Makassar: Ilmu dan Teknologi Peternakan.

BSN. (1995). Standar Nasional Daging Asap. Dalam SNI 01-3818-1995. Jakarta.

Kamulayan, B. (2008). Isolasi Bahan Bakar (Biofuels) dari Tar-Asap Cair Hasil Pirolisis Tempurung Kelapa. UGM, FMIPA. Yogyakarta: FMIPA UGM.

R., A. (2008). Pengolahan dan Pengawetan Ikan. Jakarta: Bumi Aksara.

Sayang Nur S., Abustam E, Said, MI. (2012).

Soeparno. (2005). Ilmu dan Teknologi Daging (Ke empat ed.). Yogyakarta: UGM Press.

Suryaningsih, L. P. (2009). Perendaman Daging Domba Garut dengan berbagai Konsentrasi Asap Cair Tempurung Kelapa terhadap Jumlah Total Bakteri, Daya Awaet, dan Akseptabilitas.

Wibowo, S. 2002. Industri Pengasapan Ikan. Penebar Swadaya. Yogyakarta. 